\title{
Effect of simvastatin on coagulation in rats with abdominal sepsis
}

Efeito da sinvastatina na coagulação em ratos com sepse abdominal

Irami Araújo-Filho, MD, PhD; Camila Carlos Tavares; Nathalia Louise Rosario Alves Mota; Amália Cinthia Meneses Rêgo, MD, PhD; Ítalo Medeiros Azevedo; Vanessa de Fátima Lima Paiva Medeiros; Aldo Cunha Medeiros, MD, PhD.

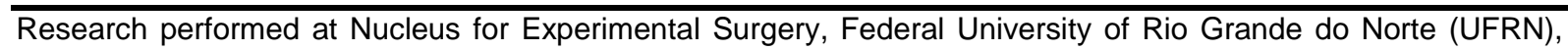
Brazil.

Financial support: none.

Conflict of interest: none

Correspondence address: Irami Araújo Filho, Department of Surgery, Federal University of Rio Grande do Norte, at Av. Nilo Peçanha 620, Natal, RN, Brazil, Email: irami.filho@uol.com.br

Submitted: 25 february 2013. Accepted, after review: 25 march 2013.

\begin{abstract}
Objective: This study aimed to evaluate the Simvastatin pleiotropic effects in coagulation on rats with abdominal sepis. Methods: Twelve Wistar rats (three months, 273-297g) were randomly assigned to abdominal septic group $(n=6)$, induced by cecal ligation and pucture (CLP) and septic group with a previous drug treatment $(n=6)$. The Simvastatin/CLP group was treated with oral simvastatin (10 $\mathrm{mg} / \mathrm{Kg}$ ), eighteen and two hours before the CLP procedure or normal saline solution $0.9 \%$. Peripheral blood laboratory determinations: Platelets, ativated troboplastin parcial time, activated coagulation time, protrombin time, trombin time, fibrinogen dosage, factor VII and factor VIII. Statistical analysis was done by ANOVA and Tukey test, with $p<0.05$. Results: It wasn't found any significant statistic differences between the groups. Conclusion: Simvastatin did not change the coagulation in rats with abdominal sepsis, according to this experimental model.
\end{abstract}

Key words: Coagulation. Sepsis. Peritonitis. Simvastatin.

\section{RESUMO}

Objetivo: Avaliar o efeito da sinvastatina na coagulação em ratos portadores de sepse de origem abdominal. Métodos: Foram utilizados 12 ratos Wistar, 3 meses de idade, 273-297g. Os animais foram divididos aleatoriamente em: Grupo sepse abdominal, submetidos à ligadura e punção do ceco (LPC), sem receber tratamento medicamentoso prévio e Grupo LPC/Sinvastatina, submetidos à ligadura e punção do ceco, tratados com $10 \mathrm{mg} / \mathrm{Kg}$ de sinvastatina via oral por sonda de gavagem $18 \mathrm{~h}$ e $2 \mathrm{~h}$ antes da ligadura e punção do ceco. Dosagens Laboratoriais: Hemograma; Tempo de Tromboplastina Parcial Ativada (TTPa); Tempo de Protrombina (PT); 
Contagem e morfologia de plaquetas; Fator VII; Fator VIII. As comparações dos grupos foram realizadas pela análise de variância ANOVA seguido pelo Teste de Turkey. Sendo os resultados considerados estatisticamente significativos quando $p<0,05$. Resultados: Não foram encontradas diferenças estatisticamente significativas entre os dois grupos. Conclusão: A sinvastatina não alterou a coagulação em ratos portadores de sepse abdominal, de acordo com o modelo experimental usado.

Descritores: Sepse. Peritonite. Coagulação. Sinvastatina.

\section{INTRODUCTION}

Sepsis is a severe clinical syndrome caused by infectious agent associated to bacteremia and systemic inflammatory response syndrome, which includes some physiological mechanisms of defense, in order to limit and repair tissue injury ${ }^{1}$.

All the support and advancement of anti-infective therapy, which has been aggressive and early, was not enough to change the lethality of sepsis, which is high, ranging between $30 \%$ and $50 \%$ of cases, ranking 11 th overall cause of death in the United States in the year 2000. In Brazil, the results indicate a mortality rate like that found in other countries. Studies conducted in intensive care units from several states show a high incidence of sepsis, severe sepsis and septic shock, ranging from $16 \%$ to over $50 \%$ of hospitalized patients with a high mortality in this risk population ${ }^{2}$.

Physiologically, the immune system remains in balance and harmony between inflammation and anti-inflammation, however, in response to an infectious agent, for unknown reasons, there is an exacerbation by an amplified cascade of inflammatory cytokines, like tumor necrosis factor-alpha (TNF- $\alpha$ ), interleukin-1beta (IL-1 $\beta$ ) and Interleukin-6 (IL-6), with the final outcome a breakdown of homeostasis, with fatal outcome or resolution. The resolution occurs when there is a suitable modulation of the inflammation and removal of the harmful agent. The intensity and duration of any response, depends not only from patient's genetic characteristics, but from the virulence and quantity of the infecting organism ${ }^{3}$.

In the investigation of this inflammatory response, it was noticed that a large number of mediators are able to activate endothelial cells, which respond with important structural and functional changes, resulting in increased platelet adhesion and leukocyte traffic. An important factor in septic endothelial dysfunction comes from the high vascular permeability, resulting in redistribution of body fluid and edema. The leakage of fluid from the intravascular space contributes to hypotension and hypovolemia, important signs of this syndrome ${ }^{4}$. The progression to multiple organ dysfunction is a common complication, which has no clear pathogenesis. It is suggested that the initiation of the reactions chain is related to disseminated intravascular coagulation, which culminates in the formation and deposition of fibrin in the microvasculature, accompanied by an inhibition of fibrinolysis, resulting in failure of systemic circulation. Paradoxically, the consumption of coagulation factors and 
interference of the products of fibrin degradation may lead eventually to diffuse hemorrhage ${ }^{5}$.

Action at the start of this pathophysiological reactions sequence involves the management of coagulopathy. The inhibition of coagulation seems to be a viable therapeutic option and inhibitors of 3-hydroxy-3-methilglutaril coenzyme A (HMGCoA) reductase inhibitors, known as statins, cholesterol lowering agents with pleiotropic actions independent of cholesterol, could be used in this context. Among other actions, statins promote immune modulation, improves endothelial dysfunction by increased bioavailability of nitric oxide (NO), atherosclerotic plaque stabilization, regulation of angiogenesis, reduction in inflammatory response and antithrombotic properties $^{6}$.

In patients treated with statins, a marked reduction in the generation of thrombin has been observed, because of the modulation on cascade of blood coagulation by the assembly of three complexes of enzymes and cofactors dependent on $\mathrm{K}$ vitamin. Thus, analyzing the coagulation pathways becomes important to evaluate the mechanism of action of statins and, accordingly, it makes necessary more specific studies ${ }^{7}$.

Results of previous studies involving the mechanisms of action at molecular level of statins confirm its effect on coagulation in vitro, but call attention to the interaction with other biological factors can alter the drug pharmacodynamic ${ }^{6}$. The majority of clinical trials evaluating the impact of statins in sepsis are retrospective cohort studies, in which are more difficult to control the uniformity of biases and patient characteristics, especially the tendency of the group that made previous use of statins, or have comorbidities. A systematic review by Dobesh et al. raises these existing studies, highlighting the importance of controled factors, to have a real dimension of the effectiveness of statins in septic conditions. Randomized controlled studies are lacking in the literature ${ }^{8}$.

The present study aimed to investigate the effect of simvastatin on coagulation in rats, using an experimental model of abdominal sepsis by cecal ligation and puncture (CLP) associated to simvastatin drug treatment, analyzing its benefit on prevention of severe coagulation disturbances, characteristic sign of sepsis.

\section{METHODS}

\section{Animals}

Twelve Wistar rats, three months old, weighing between 273-297g were used, obtained from the vivarium of the Center for Health Sciences of Federal University of Rio Grande do Norte, Brazil. We followed all the precepts of ethics in animal studies provided by Brazilian guidelines. The animals were randomly selected and divided randomly into two equal groups of six each. Animals from the Control group was only submitted to cecal ligation and puncture (CLP), without receiving prior drug 
treatment and animals from experimental group underwent CLP associated with drug therapy with simvastatin, administered orally $10 \mathrm{mg} / \mathrm{Kg}$ by gavage probe $18 \mathrm{~h}$ and $2 \mathrm{~h}$ before sepsis induction. After an acclimatization period of 24 hours, at a temperature of $22^{\circ} \mathrm{C}$, with food and water ad libitum, the animals were fasted for $12 \mathrm{~h}$ before surgery. Male rats had physiology and similar metabolism due to lineage, similar weight and age.

Anesthesia was induced with an intramuscular injection (IM) of $0.2 \mathrm{~mL} / 100 \mathrm{~g}$ of a solution of ketamine $(50 \mathrm{mg} / \mathrm{mL})$ and xylazine $(20 \mathrm{mg} / \mathrm{mL})$ and animals were operated under aseptic conditions. The rats were maintained on spontaneous breathing during the procedure. We performed abdominal wall depilation and antisepsis with $1 \%$ povidone followed by placement of sterile drapes. A $3 \mathrm{~cm}$ midline laparotomy was performed. The cecum was exposed and ligature made using cotton $3-0,1 \mathrm{~cm}$ from ileum penetration, preventing intestinal obstruction. The punctures were performed at three points in the cecal wall with $22 \mathrm{~F}$ needle. The cecum was then gently pressed to permit egress of feces and then replaced in the abdominal cavity. The abdominal incision was sutured in two layers with nylon 4-0.

\section{Variables}

The variables used to assess the effectiveness of simvastatin in the coagulopathy for sepsis were: platelets count, activated troboplastin partial time, activated coagulation time, protrombin time, trombin time, fibrinogen dosage, factor VII and factor VIII in both groups after 24 hours of operations. Data were expressed as mean \pm standard deviation (SD). Comparisons among groups were performed using the ANOVA followed by Student $t$ test using SPSS ${ }^{\circledR} 17$, considering significant difference when $p<0.05$.

\section{RESULTS}

No animal death were observed during the period of the study, including both the experimental and the control group. As shown in Table 1, we found that there were no statistically significant differences between the biochemical data compared in this study. So, our methods were not able of demonstrate the interference of simvastatin on coagulation in rats submitted to abdominal sepsis by CLP model.

Concerning dosages of partial thromboplastin time and the activated clotting time, it proved an elevation of absolute measurements, but no statistical significance $(p>0.05)$. However, we observed in this results a tendency toward statistical significance once the $p$ value remained lower than 0.10 . 
Table 1 - Laboratorial dosages of coagulation activity comparing control and experimental groups.

\begin{tabular}{lccc}
\hline \multicolumn{1}{c}{ Parameters } & $\begin{array}{c}\text { CONTROL } \\
\mathbf{n}=6\end{array}$ & $\begin{array}{c}\text { EXPERIMENTAL } \\
\mathbf{n}=6\end{array}$ & $\begin{array}{c}\mathbf{P}^{-} \\
\text {value }^{1}\end{array}$ \\
\hline PLATELETS (por mm) & $244.333,33 \pm$ & $244.000,00 \pm$ & 0,892 \\
Activated Troboplastin Parcial & $2.081,67$ & $3.741,66$ & \\
Timeo (TTPa/s) & $28,33 \pm 1,53$ & $27,50 \pm 1,76$ & 0,510 \\
Activated Coagulation Time & $93,33 \pm 1,53$ & $95,50 \pm 1,64$ & 0,099 \\
(TCA)/seconds & $13,00 \pm 1,00$ & $12,83 \pm 0,75$ & 0,785 \\
Protrombin Time (PT)/seconds & $10,67 \pm 1,16$ & $11,00 \pm 0,89$ & 0,644 \\
Trombin Time (TT)/seconds & $335,00 \pm 13,23$ & $322,50 \pm 19,43$ & 0,356 \\
Fibrinogen dosage mg/dL & $89,00 \pm 1,73$ & $88,67 \pm 5,32$ & 0,921 \\
Factor VII \% PROCONVERTIN & $90,67 \pm 1,53$ & $92,00 \pm 5,40$ & 0,594 \\
\hline Factor VIII \% &
\end{tabular}

1: P-value by the $t$ de Student test for independent samples. Significance level of $5 \%$. \pm : Standard deviation

\section{DISCUSSION}

The present study contributes to understand the influence of statins in prevention of alterations in sepsis-associated coagulopathy, since no study have been published correlating sepsis, simvastatin and coagulopathy. This syndrome causes a high mortality rate $-30 \%$ to $50 \%$ of cases according to Henkin et al. due to changes in clotting, leading to multiple organ dysfunction ${ }^{2}$. The use an experimental animal model with adequate randomized and controlled methodology is important, because of the existence of studies with conflicting results and confounding about this issue ${ }^{8}$.

In this study, a significant association was not found between coagulation parameters measured in rats previously treated with simvastatin before induction of sepsis.

Concerning methodological issues, some limitations can be considered. We used a short number of animals in each group $(n=6)$ and the administration of statins, which in this study was $18 \mathrm{~h}$ and $2 \mathrm{~h}$ before induction of sepsis in experimental group. According Undas et al., the minimum time of administration of simvastatin to achieve a significant result in coagulopathy of sepsis parameters could be three days. In this experiment above, after administration of a statin in hypercholesterolemic men in this period, the authors found potentiation of anticoagulant factors such as delay in prothrombin activation ${ }^{6}$. Besides this, a systematic review also confirmed that the effects of statin administration are time dependent and may have a low impact on coagulation in a short time of exposition? 
According to a study of Bertolotto et al., atorvastatin was responsible for elevating the plasma fibrinogen levels in hypercholesterolemic patients, after administration of $40-80 \mathrm{mg}$ daily. This effect have not been observed in the literature with some other statins ${ }^{10}$. Other studies, such as Seljeflot et al., also found a higher positive association between the use of atorvastatin with changes in plasma levels of coagulation factors, when compared with those using simvastatin ${ }^{11}$. On the other hand, these results are not supported by the study of Ito et. al., which showed no change comparing those statins ${ }^{12}$. Thus, the influence of statin type and its anticoagulant action in sepsis is an interesting hypothesis that should be studied.

Although it is known that the above mentioned factors (dose, duration and type of statin) might influence their pleiotropic effect on coagulation and sepsis, drug interactions should be taken into consideration, because the effect in vivo tends to be less than the in vitro due to complex interactions with other systems ${ }^{4,8}$. Thus, it can be inferred that many studies that prove the efficacy of statins in vitro may not demonstrate the same results in vivo, due to factors such as dosage, treatment time, environmental and physiological conditions ${ }^{4}$.

Assuming that statins have been used in patients with sepsis in some trials, the theme shows up relevant and future studies should be encouraged.

In conclusion, our data suggest that simvastatin did not change significantly the coagulation in rats with abdominal sepsis, according to the here in used experimental model. Future studies are needed to better clarify the phenomena involved in the relationship among sepsis, coagulation and statins.

\section{REFERENCES}

1. Araújo-Filho I, Jácome DT, Rêgo AC, Azevedo IM, Egito ES, Medeiros AC. Effectof the simvastatin in abdominal sepsis of diabetic rats. Rev Col Bras Cir. 2010;37(1):39-44.

2. Al Mohajer M, Darouiche RO. Sepsis syndrome, bloodstream infections, and device-related infections. Med Clin North Am. 2012;96(6):1203-23.

3. Machado FR, Silva E. Coagulation and sepsis. Endocr Metab Immune Disord Drug Targets. 2006;6(2):175-82.

4. Schouten M, Wiersinga WJ, Levi M, van der Poll T. Inflammation, endothelium, and coagulation in sepsis. J Leukoc Biol. 2008;83(3):536-45.

5. Zeerleder S, Hack CE, Wuillemin WA. Disseminated intravascular coagulation in sepsis. Chest. 2005;128(4):2864-75.

6. Undas A, Celinska-Löwenhoff M, Brummel-Ziedins KE, Brozek J, Szczeklik A, Mann KG. Simvastatin given for 3 days can inhibit thrombin generation and activationof factor $\mathrm{V}$ and enhance factor $\mathrm{Va}$ inactivation in hypercholesterolemic patients. Arterioscler Thromb Vasc Biol. 2005;25(7):1524-5. 
7. Undas A, Brummel KE, Musial J, Mann KG, Szczeklik A. Simvastatin depresses blood clotting by inhibiting activation of prothrombin, factor $\mathrm{V}$, and factor XIII and by enhancing factor Va inactivation. Circulation. 2001;103(18):2248-53.

8. Dobesh PP, Swahn SM, Peterson EJ, Olsen KM. Statins in sepsis. J Pharm Pract. 2010;23(1):38-49.

9. Krysiak R, Okopień B, Herman Z. Effects of HMG-CoA reductase inhibitors on coagulation and fibrinolysis processes. Drugs. 2003;63(17):1821-54.

10. Bertolotto A, Bandinelli S, Ruocco L, Lo Faro A, Penno G, Navalesi R. More on the effect of atorvastatin on plasma fibrinogen levels in primary hypercholesterolemia. Atherosclerosis. 1999;143(2):455-7.

11. Seljeflot I, Tonstad S, Hjermann I, Arnesen H. Reduced expression of endothelial cell markers after 1 year treatment with simvastatin and atorvastatin in patients with coronary heart disease. Atherosclerosis. 2002;162(1):179-85.

12. Ito MK. The effects of converting from simvastatin to atorvastatin on plasminogen activator inhibitor type-1. J Clin Pharmacol. 2001;41(7):779-82. 